(C) Elsevier/INRA

Original article

\title{
Dynamic management of genetic resources: first generation analysis of sunflower artificial populations
}

2

Institut National de la Recherche Agronomique, Service de Recherches intégrées sur les

E Belhassen ${ }^{1}$, G Augé ${ }^{1}, \mathrm{~J} \mathrm{Ji}^{1}$, C Billot ${ }^{2}$,

$\mathrm{J}$ Fernandez-Martinez ${ }^{1}$, J Ruso ${ }^{3}, \mathrm{D}$ Varès ${ }^{1}$

1 Institut National de la Recherche Agronomique, Montpellier, Génétique et Amélioration des Plantes, 34130 Mauguio;

Productions végétales, Domaine de Gotheron, 26320 St-Marcel-lès-Valence, France;

${ }^{3}$ CSIC, Instituto de Agronomia y Proteccion vegetal, 14080 Cordoba, Spain

Summary - Twenty-two artificial populations composed of wild, interspecific and cultivated Helianthus genotypes were constructed in southern Europe. The long-term objective was to develop a methodology for dynamic management of sunflower genetic resources. Eight parental populations of 75 individuals each were analysed for agromorphological traits. The genetic variability was very large. The wild and interspecific genotypes were clearly differentiated from the cultivated ones. The first generation of offspring was analysed by isozyme characterisation ( 5 alleles) and restriction fragment length polymorphism (RFLP) (using a ribosomal gene spacer probe discriminating several parental genotypes). Differences in frequencies of isozyme alleles between parental and offspring samples were consistent with the existence of intercrosses between wild, interspecific and cultivated genotypes. Half the RFLP patterns in the offspring generations were similar to parental patterns and the other half were new combinations of parental haplotypes. These patterns could have resulted from intercrosses. Although genetic variability in the artificial populations may decrease over time, new genotypes can be generated through intercrosses and will contribute to enlarge sunflower genetic resources.

genetic resource / introgression / gene flow / artificial population / sunflower

Résumé - Gestion dynamique des ressources génétiques : analyse des premières générations dans des populations artificielles de tournesol. La gestion ex situ des ressources génétiques utilise essentiellement des méthodes de conservation statique. Les ressources génétiques disponibles sont exploitées dans des croisements entre lignées et ressources originales qui se poursuivront par des programmes de sélection classique. Des méthodologies de gestion dynamique des ressources génétiques ont été proposées dans lesquelles les forces évolutives naturelles (dérive, sélection naturelle, flux géniques) sont utilisées pour faire évoluer la variabilité génétique. En définissant une méthodologie de ges- 
tion dynamique des ressources génétiques pour le tournesol, des populations artificielles ont été créées dans le but d'enrichir la variabilité génétique utilisable. Les populations artificielles sont constituées de 75 individus issus de 3 groupes de génotypes : les sauvages (espèces annuelles du genre Helianthus), les interspécifiques (obtenus par croisements entre espèces sauvages et lignées) et les cultivés. Les flux polliniques entre individus sont non contrôlés. Deux traitements sont appliqués : un traitement contrôlé dans lequel les conditions sont proches de celles rencontrées dans une culture classique; un traitement non contrôlé consistant en une intervention humaine minimum avec libre action de la sélection naturelle. Les populations artificielles sont implantées dans 4 localités (Montpellier, Valence, Toulouse, Cordoue-Espagne) avec 2 répétitions (soit 4 populations) par localité. L'analyse discriminante des génotypes parentaux pour 7 caractères quantitatifs montre une différenciation nette entre le groupe des génotypes sauvages et celui des cultivés. Les génotypes interspécifiques sont proches du groupe des sauvages. Une étude de la variabilité génétique de la première génération de descendants, a été réalisée à l'aide de marqueurs RFLP (polymorphisme de longueur de fragment de restriction utilisant un espaceur interne des gènes nucléaires ribosomiques) et isoenzymatiques. La moitié des profils RFLP dénombrés parmi les descendants sont nouveaux; ils correspondent à des combinaisons simples entre haplotypes parentaux et peuvent être considérés comme des marqueurs d'introgression interspécifiques. Pour les isozymes, 5 allèles différencient les génotypes sauvages, interspécifiques et cultivés. Leurs fréquences varient entre les échantillons parentaux et ceux des descendants. Certains descendants de génotypes cultivés ont des allèles qui n'étaient présents que chez les génotypes parentaux sauvages. Ces variations de fréquences alléliques soutiennent également l'existence d'intercroisements. Ces résultats montrent que le dispositif de populations artificielles mis en place peut permettre le brassage de gènes entre génotypes génétiquement éloignés, et pourra aboutir à l'enrichissement des ressources initiales.

ressource génétique / introgression / flux génique / population artificielle / tournesol

\section{INTRODUCTION}

Plant breeders need genetic diversity to improve their material the face of new objectives or new biotic threats. The problem of the loss of genetic variability due to directional selection applies to a large number of crops. Thus, methodology for genetic resource management has been the subject of extensive investigations. Plant genetic resources are currently conserved using in situ or ex situ strategies: in situ conservation involves the natural location of the species; ex situ approaches require low-temperature conservation of seeds. Initial genetic variability is successfully being maintained by ex situ methods. However, genetic drift and seed mortality lead to significant loss of variability.

An experimental method of genetic resource management has been proposed by Allard (Allard, 1988, 1990) in which resources are conserved in the usual environment. In this approach, the genetic variability is exposed to natural evolutionary pressures (selection, mutation, drift, etc) and can evolve with its environment. This methodology has been tested on few species. Allard analysed the evolution of genetic variability in barley (Hordeum vulgare) (Allard, 1988). Starting from a synthetic population of 28 barley varieties mixed in 1929 (Harlan and Martini, 1929), more 
than 50 generations were followed under natural evolutionary conditions. Measurements of quantitative traits in these experimental populations of barley show that a cumulative increase in reproductive capacity continued for many years (Allard, 1988). Similarly, there are significant changes in allelic frequencies of marker loci (morphological traits, isozymes and rDNA). Fifty years of evolution of these populations results in "increased adaptedness to the local environment and... in striking ecogenetic differentiation" (Allard, 1988). Similar experiments have been carried out on lima bean (Phaseoulus lunatus L) (Allard and Workman, 1962) and wheat (Triticum aestivum L) (David, 1992). The original methodology proposed by Allard for barley was applied using one location and one species. The experimentation on wheat also used one species but was multisite in order to diversify selection forces.

We have designed a similar methodology of dynamic resource management adapted to sunflower (Helianthus annuus L). The genetic resources for sunflower include almost all the Helianthus species, and thus an appropriate methodology would be multisite and include numerous Helianthus species. Artificial populations including wild, interspecies and cultivated genotypes, were constructed in 4 Mediterranean locations. The parental population of 75 individuals was analysed for agromorphological traits. The first generation of offspring were analysed for RFLP (restriction fragment length polymorphism), using the ribosomal spacer (rDNA) and isozyme analysis. The long-term objectives of this experiment are to follow the genetic evolution of these artificial populations and to detect potentially valuable genotypes to enlarge sunflower genetic resources.

\section{MATERIALS AND METHODS}

\section{Experimental design}

The design consisted of 22 artificial populations, and 11 sites in 4 locations. Three locations were in France, Montpellier (4 sites), Valence (2 sites), and Toulouse (2 sites), and one was in Spain (Cordoba, 3 sites). Two populations were installed per site and with 2 treatments in each: one was controlled (with irrigation, cleaning, fungicide, etc) and one non-controlled (no irrigation, no cleaning, no tilling, etc). Each controlled population was cultivated under an insect-proof cage with a beehive inside. The non-controlled population was isolated by distance from other sunflower fields and a beehive was maintained close to it.

Fifteen genotypes were chosen: 5 wild species; 5 interspecies hybrids; and 5 inbred lines (table I). All the genotypes were diploid, annual, inter-fertile with the sunflower when hand pollinated, and had non-sterilising cytoplasms. Each population was 75 plants: 5 plants of each of the 15 genotypes were planted randomly within a $7 \mathrm{~m}$ square $\left(50 \mathrm{~m}^{2}\right)$.

The 2 groups of populations were perpetuated differently: for the non-controlled populations, the number of heads per individual was scored and half of them were harvested; thus one pool per population per generation was obtained for further use as a reserve of seeds (for eventual new populations and for genetic diversity analysis). The other half of the seeds were naturally disseminated, and the populations were perpetuated by spontaneous seedlings. For the controlled 
Table I. Characteristics of the genetic material.

\begin{tabular}{|c|c|c|}
\hline Genotype number & Origin & Type \\
\hline $\begin{array}{l}376 \\
585 \\
218 \\
197 \\
200\end{array}$ & $\begin{array}{c}H \text { annuus } \\
H \text { argophyllus } \\
H \text { debilis cucumerifolius } \\
H \text { niveus canescens } \\
H \text { petiolaris fallax }\end{array}$ & $\begin{array}{l}\text { Wild } \\
\text { Wild } \\
\text { Wild } \\
\text { Wild } \\
\text { Wild }\end{array}$ \\
\hline $\begin{array}{l}\mathrm{I} 1 \\
\mathrm{I} 2 \\
\mathrm{I} 3 \\
\mathrm{I} 4 \\
\mathrm{I} 5\end{array}$ & $\begin{array}{c}H \text { argophyllus } X W G \\
H \text { neglectus } X M H \\
H \text { petiolaris } p X R H A 274 \\
H \text { petiolaris } p X R H A 274 \\
H \text { praecox praecox } X W G\end{array}$ & $\begin{array}{l}\text { Interspecific } \\
\text { Interspecific } \\
\text { Interspecific } \\
\text { Interspecific } \\
\text { Interspecific }\end{array}$ \\
\hline $\begin{array}{l}89 \mathrm{~B} 1 \\
89 \mathrm{HR} 3 \\
\text { AL5.4 } \\
\text { HA89 } \\
\text { RHA265 }\end{array}$ & $\begin{array}{l}H \text { annuus } \\
H \text { annuus } \\
H \text { annuus } \\
H \text { annuus } \\
H \text { annuus }\end{array}$ & $\begin{array}{l}\text { Cultivated } \\
\text { Cultivated } \\
\text { Cultivated } \\
\text { Cultivated } \\
\text { Cultivated }\end{array}$ \\
\hline
\end{tabular}

populations, all the seeds were harvested and counted for each plant. Seventyfive offspring were required for the next generation since the initial row and plant spacing were maintained. The simplest way of sampling would have been to take a number of offspring per genotype, estimated linearly from the seeds produced by this genotype. However, this would have resulted in offspring of only the 2 or 3 genotypes which were most abundant producers (such as wild Helianthus annuus). To minimise this bias, the number of offspring to be planted $(O)$ was calculated as a logarithmic function of the seeds produced $(S)$ :

$$
O=75 \times \log (S) / \Sigma(\log (S))
$$

Thus, genotypes that produced few seeds had some chance of being represented in the next generation.

\section{Characterisation of parental populations}

Quantitative traits were measured on each individual of the artificial populations. We present an analysis of 8 populations from Montpellier. Seven traits were scored: height at maturity, mean head diameter, head number, seed number and weight, flowering duration, and blooming date.

Analysis of variance was performed for each of the 3 classes of genotypes (wild, interspecies and lines). A general model in which the 3 classes were mixed or hierachized was not possible because the homogeneity and normality of variances were not respected for all variables except height at maturity. Therefore, the following fixed model was used: $P_{i j k l}=\mu+S_{i}+G_{j}+T_{k}+(S \times G)_{i j}+(S \times T)_{i k}+(G \times T)_{k j}$ $+(S \times G \times T)_{i j k}+E_{i j k l}$, where $\mu$ is the grand mean, $S_{i}(i=1-4)$ the site effect of the $i$ th site, $G_{j}(j=1-5)$ the genotype effect of the $j$ th genotype, $T_{k}(k=1-2)$ the 
treatment effect of the $k$ th treatment, $E_{i j k l}(l=1-5)$ the residual variation, and $(S \times G)_{i j},(S \times T)_{i k},(G \times T)_{k j}$, and $(S \times G \times T)_{i j k}$ the interactions between effects.

To visualise the genetic variability of the material, factorial discriminant analysis was used on those variables. The Mahalanobis distances were calculated to estimate distances between classes, taking into account the within-class variations.

\section{First generation analysis}

The first generation offspring of a non-controlled population were studied for molecular and isozyme markers. RFLP analysis were carried out using the EcoRIBamHI fragment of the nuclear ribosomal spacer (R3) isolated from sunflower (Choumane and Heizmann, 1988). DNA was extracted from $1 \mathrm{~g}$ of fresh leaves using the procedure of Dellaporta et al (1983). Southern blotting on nylon membrane (Amersham $\mathrm{N}+$ ) and ${ }^{32} \mathrm{P}$ random priming hybridisation (Pharmacia kit) were done according to the suppliers' instructions.

The RFLP patterns of the ribosomal loci of 10 individuals per ecotype were analysed to screen for variability within each genotype. The $R 3 / B a m H I$ patterns of each spontaneous offspring growing in the population were determined.

One-day-old seedlings were used for isozyme analysis following the procedure described in Quillet et al (1992). Three loci which differentiated some of the parental genotypes were analysed: $P G I 3, S D H 1$ and $S D H 2$. Samples of parental ecotypes and offspring of each parent of the controlled population were analysed. The sample sizes (given below in table V) were smaller for parental cultivated genotypes (with a minimum of 25 individuals) than for the wild type, since fixed lines are genetically homogeneous.

\section{RESULTS}

\section{Characterisation of parental populations}

The analysis of variance of the 7 traits scored was highly significant for the model for all variables for wild and interspecies genotypes (table II). For lines, this was the case only for height at maturity and flowering duration. The effect of treatment was significant for 3 classes simultaneously only for the height at maturity, and did not influence the seed numbers. The wild species $H$ annuus produced about 10 times more akens than the other genotypes. The genotype effect was significant in wild and interspecies classes for all traits, illustrating the high variability of all the traits scored in the populations.

This variability was further illustrated with a factorial discriminant analysis (fig 1). The wide variability within single wild genotypes was illustrated by the large distribution they covered. Interspecies genotypes were distributed close to wild genotypes. Lines were relatively closely grouped for the flowering and head diameter axis (axis 2) and more scattered along the yield component axis (axis 1). Wild genotypes were distributed twice as widely. Overall, the characteristics of lines were distinct from those of interspecies and wild genotypes: the Mahalanobis distances or $D^{2}$ (which allows us to calculate distance between classes while taking into account 
Table II. Analysis of variance of 7 morphological traits of parental populations.

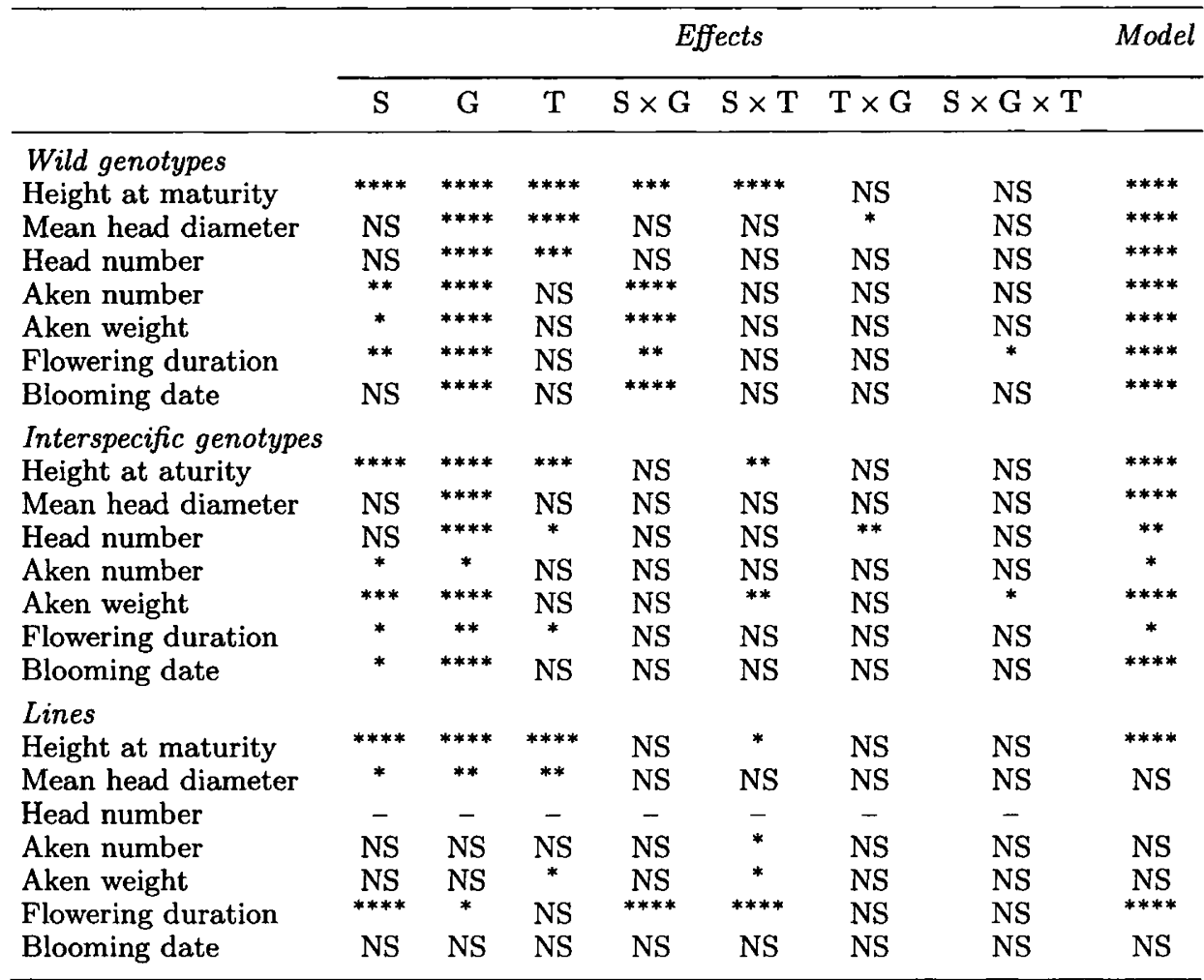

Fixed model: $P_{i j k l}=\mu+S_{i}+G_{j}+T_{k}+(S \times G)_{i j}+(S \times T)_{i k}+(G \times T)_{j k}+$ $(S \times G \times T)_{i j k}+E_{i j k l}$ where $\mu$ is the grand mean, $S_{i}(i=1,2, \ldots 4)$ the site effect of the $i$ th site, $G_{j}(j=1,2, \ldots, 5)$ the genotypic effect of the $j$ th genotype, $T_{k}(k=1,2)$ the treatment effect of the $k$ th treatment, $E_{i j k l}(1=1,2, \ldots, 5)$ the residual variation, and $(S \times G)_{i j},(S \times T)_{i k},(G \times T)_{j k},(S \times G \times T)_{i j k}$ the interactions between effects. ${ }^{*} P<0.05$; ${ }^{* *} P<0.01 ;{ }^{* * *} P<0.001 ;{ }^{* * * *} P<0.0001$; NS: not significant.

the within-class variations) were 25.3 and 26.9 respectively and interspecies and wild classes were much closer $\left(D^{2}=1.8\right)$.

\section{First generation analysis}

The RFLP marker used (R3) could discriminate between half of the wild species when hybridised on BamHI Southern blots (fig 2). The ribosomal BamHI patterns did not distinguish $H$ petiolaris, $H$ niveus, $H$ neglectus and $H$ praecox, species which are closely related (Heiser et al, 1969). The pattern of these 4 species was designed 'NP'. The 10 individuals analysed from each species were identical. 


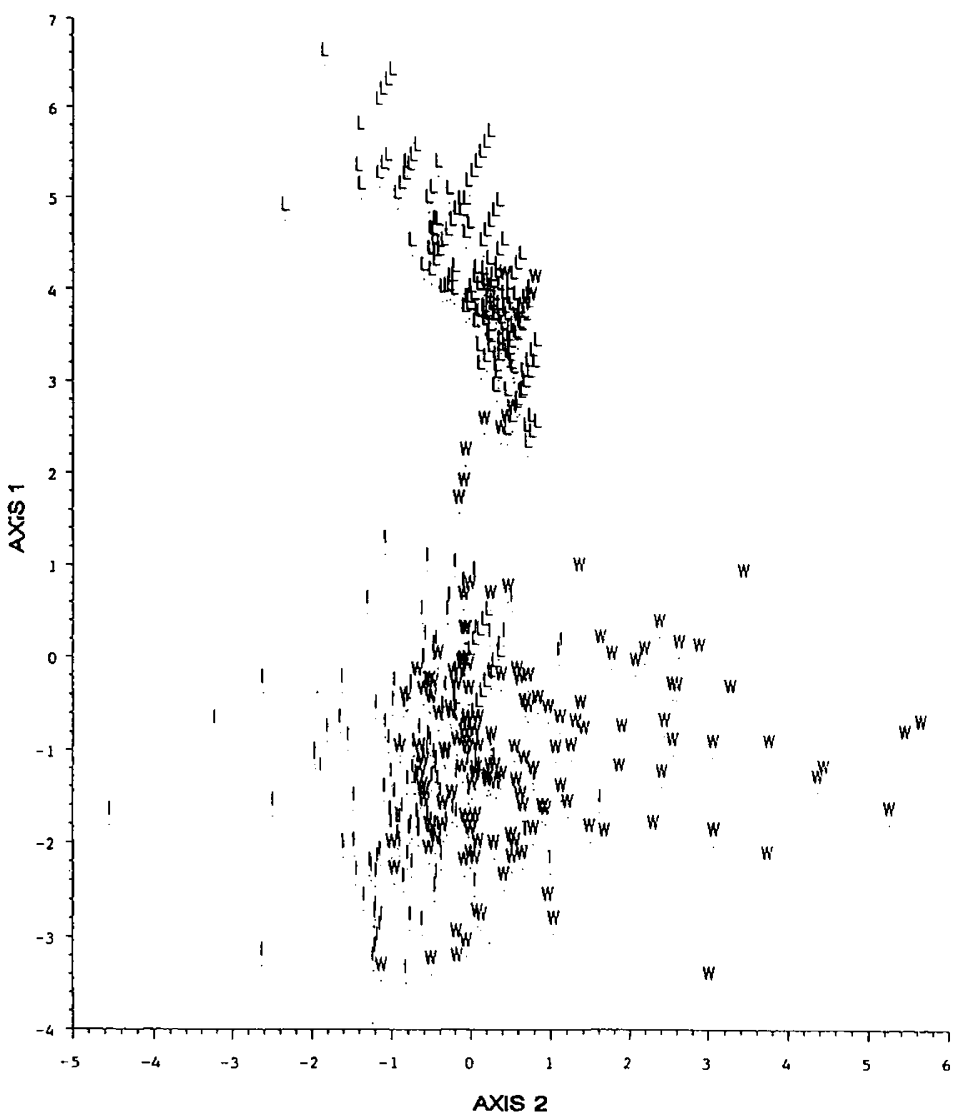

Fig 1. Factorial discriminant analysis of 7 quantitative traits in the parental genotype of the artificial populations. W: Wild genotypes; I: interspecies genotypes; L: lines. Axis 1 is a yield component axis and axis 2 is a flowering and head diameter axis.

In the first generation, 52 offspring in the non-controlled and 67 in the controlled population were analysed (fig 3 ). The RFLP patterns at the ribosomal loci for all offspring were determined and the frequency of each pattern was calculated (table III). The frequencies for each sample (parental and controlled and noncontrolled offspring) were highly significantly different $(P<0.001)$. A total of 13 different patterns were detected of which 7 were not present in the parental generation. These last patterns could be combinations of parental haplotypes (haploid RFLP patterns). For example, offspring $n^{\circ} 21$ (fig 3) had a B/NP pattern. Furthermore, a new haplotype named ' $\mathrm{X}$ ', which could not have resulted from recombination of parental types, was found for 2 offspring (table III). This haplotype presents 2 bands, at $4.1 \mathrm{~kb}$ and $2.8 \mathrm{~kb}$.

The haplotype frequencies of the offspring from the controlled population were not significantly different from those of the parents (table IV; $\chi^{2}=7.9 ; P<0.1$ ). 


$$
\begin{array}{lllllllllll}
5 & 3 & 2 & 2 & 1 & & & & & & \\
8 & 7 & 0 & 1 & 9 & & & & & & \\
5 & 6 & 0 & 8 & 7 & \text { LINES } & 12 & 13 & 14 & 15 & 11
\end{array}
$$

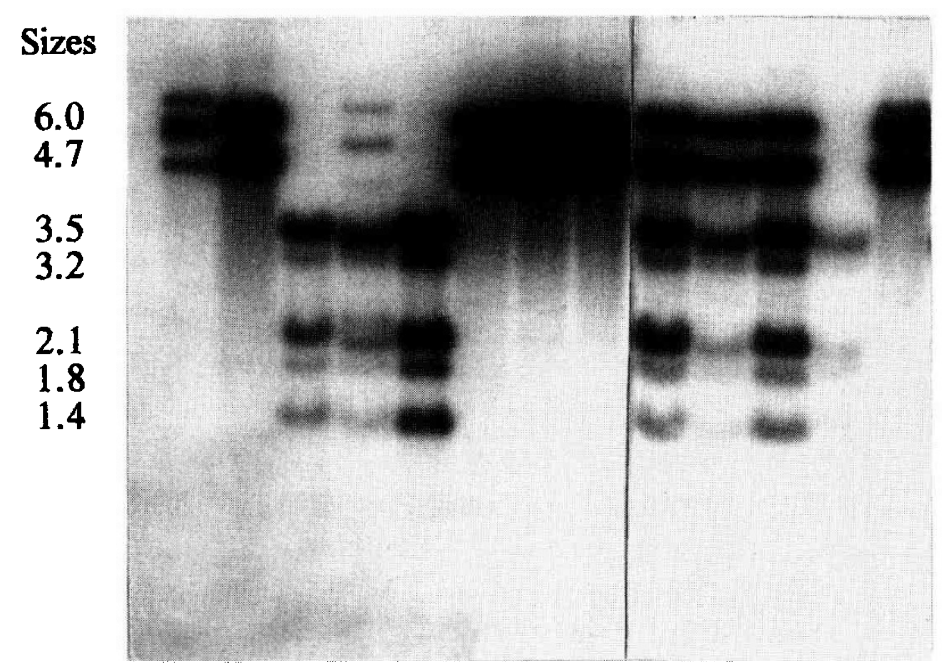

Fig 2. BamHI RFLP patterns with the nuclear ribosomal spacer probe of the parental genotypes. Sizes are given in kilobases. (see table I for genotype number codification).

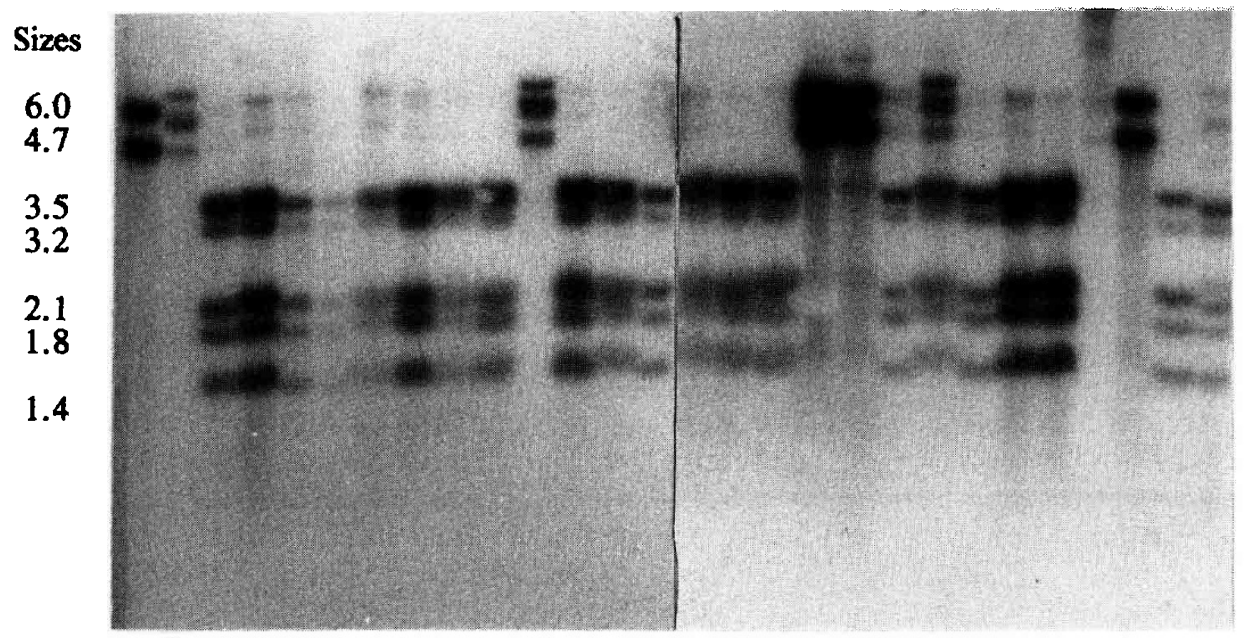

Fig 3. BamHI RFLP patterns with the nuclear ribosomal spacer probe of 28 offspring of the non-controlled population. Sizes are given in kilobases. 
Table III. Frequencies of the RFLP types in parental and offspring generations.

\begin{tabular}{llccccc}
\hline RFLP types & \multicolumn{2}{c}{ Parents } & \multicolumn{2}{c}{$\begin{array}{c}\text { Offspring of the } \\
\text { controlled population }\end{array}$} & \multicolumn{2}{c}{$\begin{array}{c}\text { Offspring of the } \\
\text { non-controlled population }\end{array}$} \\
\hline AA & 0.40 & $(30)$ & 0.22 & $(15)$ & 0.08 & $(4)$ \\
BB & 0.07 & $(5)$ & 0.03 & $(2)$ & 0.08 & $(4)$ \\
DD & 0.07 & $(5)$ & 0.03 & $(2)$ & 0.02 & $(1)$ \\
NP NP & 0.13 & $(10)$ & 0.06 & $(4)$ & 0.50 & $(26)$ \\
A B & 0.07 & $(5)$ & 0.24 & $(16)$ & 0.15 & $(8)$ \\
A NP & 0.27 & $(20)$ & 0.09 & $(6)$ & 0.06 & $(3)$ \\
BD & 0 & $(0)$ & 0.01 & $(1)$ & 0 & $(0)$ \\
B NP & 0 & $(0)$ & 0.01 & $(1)$ & 0.08 & $(4)$ \\
D NP & 0 & $(0)$ & 0.10 & $(7)$ & 0 & $(0)$ \\
X NP & 0 & $(0)$ & 0.01 & $(1)$ & 0 & $(0)$ \\
X D & 0 & $(0)$ & 0.01 & $(1)$ & 0 & $(0)$ \\
(A NP) B & 0 & $(0)$ & 0.13 & $(9)$ & 0.04 & $(2)$ \\
(A NP) D & 0 & $(0)$ & 0.03 & $(2)$ & 0 & $(0)$ \\
\hline
\end{tabular}

$\mathrm{A}=H$ annuus $; \mathrm{B}=H$ argophyllus $; \mathrm{D}=H$ debilis $c ; \mathrm{NP}=H$ niveus $c=H$ petiolaris $s p$ $=H$ praecox $=H$ neglectus. $\mathrm{X}=$ new pattern. Sample sizes are given in brackets.

However, the haplotype frequencies of the non-controlled offspring were significantly different from their parents $\left(\chi^{2}=23.1 ; P<0.001\right)$. The haplotype frequencies of the controlled and non-controlled offspring were also highly significantly different $\left(\chi^{2}=21.1 ; P<0.001\right)$.

Table IV. Frequencies of the 5 haplotypes in parental and offspring generations. Sample sizes are given in brackets (symbols as in table III).

\begin{tabular}{lcccccc}
\hline Haplotypes & \multicolumn{2}{c}{ Parents } & \multicolumn{2}{c}{$\begin{array}{c}\text { Offspring of the } \\
\text { controlled population }\end{array}$} & $\begin{array}{c}\text { Offspring of the } \\
\text { non-controlled population }\end{array}$ \\
\hline A & 0.57 & $(43)$ & 0.43 & $(29)$ & 0.19 & $(10)$ \\
B & 0.10 & $(7)$ & 0.23 & $(15)$ & 0.21 & $(11)$ \\
D & 0.07 & $(5)$ & 0.11 & $(8)$ & 0.02 & $(1)$ \\
NP & 0.27 & $(20)$ & 0.21 & $(14)$ & 0.58 & $(30)$ \\
X & 0.00 & $(0)$ & 0.02 & $(1)$ & 0.00 & $(0)$ \\
\hline
\end{tabular}

Isozyme analyses of 3 loci identified 5 alleles which were absent in at least one genotype class (table V). In the parental genotypes, PGI3-e, SDH1-e and SDH2-b were present only in wild genotypes, while PGI3-h was only found in interspecies genotypes. SDH1-b was not found in the cultivated genotypes. Allele frequencies were different in parental and offspring samples. In the offspring samples, some alleles appeared in classes from which they were absent in the parental generation. For example, $15 \%$ and $6 \%$ of the offspring of the interspecies and cultivated classes respectively, possessed the SDH2-b allele whereas this allele was only present in the wild parent class. The frequency differences between the parental and the 
offspring samples were highly significant $\left(\chi^{2}=29.4 ; P<0.001\right)$. The frequency of allele SDH1-b in the line class increased significantly from 0 to $6 \%\left(\chi^{2}=21.4\right.$; $P<0.001$ ) from parental to offspring generation. For the 3 other alleles, the frequency differences between generations were not significant.

Table V. Allele frequencies of parental and offspring samples for the 3 genotypic classes (sample sizes in backets).

\begin{tabular}{lcccccc}
\hline Alleles & \multicolumn{3}{c}{ Parental samples } & \multicolumn{3}{c}{ Offspring samples } \\
& Wilds & Hybrids & Lines & Wilds & Hybrids & Lines \\
\hline PG13-e & 0.06 & 0 & 0 & 0.01 & 0.02 & 0 \\
& $(170)$ & $(135)$ & $(29)$ & $(131)$ & $(128)$ & $(152)$ \\
PG13-h & 0 & 0.05 & 0 & 0.01 & 0.02 & 0 \\
& $(170)$ & $(135)$ & $(29)$ & $(131)$ & $(128)$ & $(152)$ \\
SDH1-b & 0.01 & 0.26 & 0 & 0.05 & 0.18 & 0.06 \\
& $(159)$ & $(131)$ & $(25)$ & $(139)$ & $(86)$ & $(145)$ \\
SDH1-e & 0.13 & 0 & 0 & 0.10 & 0.05 & 0 \\
& $(159)$ & $(131)$ & $(25)$ & $(139)$ & $(86)$ & $(145)$ \\
SDH2-b & 0.08 & 0 & 0 & 0.03 & 0.15 & 0.06 \\
& $(167)$ & $(129)$ & $(25)$ & $(128)$ & $(77)$ & $(145)$ \\
\hline
\end{tabular}

\section{DISCUSSION}

The study of the parental and first generation of artificial populations of sunflower in south Europe allows a general description of the initial artificial population. In the parental generation the 7 agromorphological characters were very variable. This variability was dependent on the genotype, but not on the treatment (table II). This is probably due to the absence of drought and the low level of biotic aggression during the first year. One wild genotype ( $H$ annuus) was much more vigorous (as assessed from height and seed production) than the other genotypes. The interaction between site and genotype were almost never significant for interspecies and line material. For wild species, the site effect on genotype behaviour was significant for all variables except for head diameter and head number. In contrast, the treatment/genotype interaction was almost never significant. In other words, good genotypes remain good whatever the treatment. However, as the differences between the treatments were small this year, the analysis should be continued for several years.

Factorial discriminant analysis revealed large between- and within-group genetic variability (fig 1). This could be due to the dominant effects of wild over cultivated traits. Such dominant effects have been observed in artificial interspecies hybrids, for several characters such as yield, branching, and oil content where hybrids exhibit wild traits (Heiser et al, 1969; Serieys, personal communication).

The study of the rDNA patterns of the first generation offspring in controlled and non-controlled populations detected new types of patterns not present in the 
parental generation (fig 3 ; table III). Of the 13 patterns observed in the offspring generations, only 6 were present in the parental generation. The 7 new patterns were simple combinations of parental haplotypes, and thus argue for the existence of inter-crosses within artificial populations. The most frequent inter-crosses seemed to occur between $\mathrm{H}$ argophyllus (haplotype B) or $\mathrm{H}$ annuus (haplotype A) and NP wild or interspecies genotypes (table III).

A new haplotype $(\mathrm{X})$ detected in the offspring of the controlled population was clearly not a simple recombination of parental haplotypes. The construction of a restriction map would help to determine whether it appeared through mutation or some insertion/deletion. It would be also interesting to follow its frequency over several generations.

The distribution of haplotypes in the offspring was significantly different from that of the parents. In the offspring of the controlled population, the frequency of $H$ argophyllus (B) haplotype was double that in the parent population. This was also the case in the non-controlled population for $H$ argophyllus and NP haplotypes (table IV), whereas the frequency of $H$ annuus (A) decreased by more than half. Assuming that the ribosomal marker correctly reflects inter-crosses, the $H$ argophyllus genes are wildely disseminated in the first generation; the frequency of 'AB' RFLP type in the offspring generations increased 2-fold in the non-controlled population and 3 -fold in the controlled one, as compared to the parental population. This species is well known to be drought tolerant. However, these results could also be explained by genetic drift since the effective sizes of the populations are small.

It could be argued that the introgression observed involved only the rDNA and did not correctly reflect the whole genome. However, this probe has been widely used to identify species or genera of different plant families and the phylogenic trees obtained are comparable to trees based on other characters (Choumane and Heizmann, 1988; Zimmer et al, 1988; Springer et al, 1989; Cordesse et al, 1990; Delseny et al, 1990; Glaszmann et al, 1990; Rieseberg et al, 1990). For the artificial populations, botanical observations of spontaneous offspring reveal some potential hybrid plants with intermediate traits, consistent with the existence of introgressions in the first generation (results not shown). In the literature, crosses between annual Helianthus species have frequently been reported (see, for example, Heiser et al, 1969). The hybrids obtained can be viable and fertile. Several in situ introgressions have also been identified on the basis of molecular inferences (Rieseberg et al, 1990; Dorado et al, 1992).

All species of the Helianthus genus are insect pollinated. Introgressions could be disadvantaged if pollinators were specific for a single species. However, experiments of artificial interspecies crosses that were carried out in our laboratory, show that introgressions are more successful with insects (bees, bumblebees) in cages than manual crosses (Meynie, personal communication). In the artificial population experiments described, a beehive was installed close to each population.

The isozymic analysis also supports the existence of exchanges between classes of genotypes. Some exclusive alleles were detected in certain offspring classes from which they were absent in the parental classes (table V). Such exchanges were preferentially observed between wild and interspecies genotypes. 


\section{CONCLUSION}

High genetic variability of starting artificial populations is an important criteria for dynamic resource management (Allard, 1988; David, 1992). Natural selection has been reported after several generations in artificial populations of barley for the mating system (Kahler et al, 1975) and of wheat for disease resistance (Henry et al, 1991). The genetic variability of artificial sunflower populations was large. RFLP and isozyme analysis of the first generation in controlled and non-controlled populations show large changes in frequencies as compared to parental generation. New types appeared which were presumably inter-crosses between wild, interspecies and cultivated parental genotypes.

The evolution of the populations will probably result in a loss of genetic variability due to drift and/or selection. To document this process, it would be interesting to follow the evolution of the markers used in this experiment and to increase the number of markers followed. It will also be important to sample some of the genotypes that appear in the populations if they present potentially valuable agromorphological traits. Such genotypes will be evaluated and added to the collection in Montpellier to enlarge the genetic resources of sunflower.

\section{ACKNOWLEDGMENTS}

This research was supported by INRA- programme Agrotech-Prodige grant. We thank A Bervillé, H Serieys, C Balsera, A Gil, and P Lacombe for their helpful participation.

\section{REFERENCES}

Allard RW (1988) Genetic changes associated with the evolution of adaptedness in cultivated plants and their wild progenitors. $J$ Hered 79, 225-238

Allard RW (1990) The genetics of host - pathogen coevolution. Implication for genetic resources conservation. $J$ Hered 81, 1-6

Allard RW, Workman PL (1962) Population studies in predominantly selfpollinated species. IV. Seasonal fluctuations in estimated values of genetic parameters in lima bean populations. Evolution 17, 470-480

Choumane W, Heizmann P (1988) Structure and variability of nuclear ribosomal genes in the genus Helianthus. Theor Appl Genet 76, 481-489

Cordesse F, Second G, Delseny M (1990) Ribosomal gene spacer length variability in cultivated and wild rice species. Theor Appl Genet 79, 81-88

David J (1992) Méthode de gestion dynamique de la variabilité génétique en milieu naturel: exemple de populations composites de blé. In: Proceedings of the Colloque international en hommage à Jean Pernès, 8-10 January 1992, Paris, France Dellaporta SL, Wood J, Hicks JB (1983) A plant DNA minipreparation: version II. Plant Mol Biol Rep 1, 19-21

Delseny M, McGraph JM, This P, Chèvre AN, Quiros CF (1990) Ribosomal RNA genes in diploid and amphidiploid Brassica and related species: organisation, polymorphism and evolution. Genome $33,733-744$ 
Dorado O, Rieseberg LH, Arias DM (1992) Chloroplast DNA introgression in southern California sunflowers. Evolution 46, 566-572

Glaszman JC, Lu YH, Lanaud C (1990) Variation of nuclear ribosomal DNA in sugarcane. J Genet Breed 44, 191-198

Harlan HV, Martini ML (1929) A composite hybrid mixture. J Am Soc Agr 21, 407-490

Henry JP, Pontis C, David J, Gouyon PH (1991) An experiment on dynamic conservation of genetic resources with metapopulations. In: Species conservation: A population-biological approach (Seitz A, Loeschcke V, eds). Birkhaüser Verlag, Basel, 185-198

Heiser CB, Smith DM, Clevenger S, Martin WC (1969) The north American sunflowers (Helianthus). Mem Torrey Bot Club 22, 1-218

Kahler AL, Clegg MT, Allard RW (1975) Evolutionary changes in the mating system of an experimental population of barley (Hordeum vulgare L). Proc Nat Acad Sci USA 72, 943-946

Quillet MC, Vear F, Branlard G (1992) The use of isozyme polymorphism for identification of sunflower (Helianthus annuus) inbred lines. J Genet Breed 46, 295304

Rieseberg LH, Beckstrom-Sternberg S, Doan K (1990) Helianthus annuus ssp texanus has chloroplast DNA and nuclear ribosomal RNA genes of Helianthus debilis ssp cucumerifolius. Proc Natl Acad Sci USA 87, 593-597

Springer PS, Zimmer EA, Bennetzen JL (1989) Genomic organisation of the ribosomal DNA of sorghum and its close relatives. Theor Appl Genet 77, 844-850 Zimmer EA, Jupe ER, Walbot V (1988) Ribosomal gene structure variation and inheritance in maize and its ancestors. Genetics 120, 1125-1136 